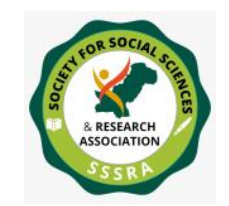

\title{
The Core Issue of Stability in Afghanistan: Envisioning the Future of Peace Deal
}

\author{
Ambreen Sikander \\ PhD. Scholar \\ Area Study Center for Europe \\ University of Karachi-Pakistan \\ ambreensikander@gmail.com \\ $\&$ \\ Dr. Rubab Hasan \\ Adjunct Faculty Member \\ International Relation Department \\ University of Karachi-Pakistan \\ rubab3149@hotmail.com
}

\begin{abstract}
Afghanistan has been a battleground to the world's largest powers. From USSR to NATO, through the Taliban, and now to the peace deal, Afghanistan holds a remarkable and yet chaotic history. Amidst the wars, some have succeeded for a limited time while others have failed. NATO has a history with Afghanistan after the 9/11 attacks in the USA. The crucial matter is how to guarantee that states budding from divergence are set with the basics on which to assemble a robust peace. The keen and incisive analysis in serenity and the Public Purse provides a precious involvement to this attempt. This article provides an analysis of the post-9/11 period and the invasion of Afghanistan by U.S. forces, focusing on the ethnic origin of the native fighters and how assorted groups engaged in dissimilar aspects of the divergence. Furthermore, this learning also highlighted the United States grasp for Afghan civil society, promotes amplified admiration for human rights, helps to fight the prohibited trade in narcotics, and continues to endow with noteworthy humanitarian uphold. The United States has owed approximately $\$ 29$ billion in civilian aid for Afghanistan and the perspective of U.S. policy headed for Afghanistan cannot be in point of truth assessed exclusively of a nearer estimation of Afghanistan's existing and emergent security, political, and economic landscapes - and their collision on U.S. strategic aims.
\end{abstract}




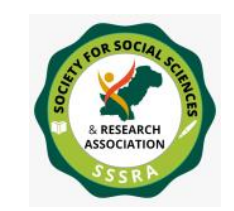

Pak. Journal of Int'L Affairs, Vol 3, Issue 2 (2020)

The Core Issue of Stability in Afghanistan...

Keywords: Afghanistan, US, Taliban, ISAF, NATO

\section{Introduction}

The North Atlantic Treaty Organization (NATO) established on $4^{\text {th }}$ April 1949, in D.C Washington. It was founded to protect Western European interests from Soviet expansionism and aggression. NATO initially consists of 12 states while some countries also signed the treaty over time - Turkey and Greece signed membership in 1952 while Spain, West Germany in 1982 and 1955. Theoretically, all state members were equal, but since it was a military alliance, it was by default dominated by the USA. This strategic alliance was doing way more than promoting stability, freedom, ideas, and the civilization of its member states. It was more like a connecting bridge of cooperation between the United States of America and The countries of Europe. Historical events like the Cold War, integration of West Germany, and travails of Suez and Vietnam NATO (North Atlantic Treaty Organization) become the principal witness. The Members of it although faced serious and immediate danger in the form of the Berlin blockade but yet avoided the missile crisis of Cuba since it was indirectly calling for a nuclear war. A sense of crisis developed on several occasions like in the year 1966 when the France Government withdrawal meanwhile Russia built-up SS-20 in the year 1977. NATO was not new to it. It became clear at the end of the geopolitical tension between the United States of America and the Soviet Union that there is no political purpose of an alliance in absence of great threat. It was no longer relevant to have a military alliance. Throughout history, we can observe the paradigm shift in NATO from power formation to the assumption of ideas that had to reshape itself according to demand. In 1962 Thomas Kuhn expressed paradigm shift as an "entire constellation of beliefs, value, techniques and so on shared by the members of a given community". It's an idea or abstract on the greater level that works to organize observation in some particular way of social life, through this we can influence about anything like the structure of the world and setting it according to a particular manner, it creates the new narrative. Old concepts must be renewed because they are unable to predict the scope of new problems. (Begum 25 July 2019.)

The United States has taken the foremost role in the overall restoration of Afghanistan by providing billions of dollars to the Afghan national security forces, building countrywide Infrastructure, government, and learning institutions. In 2005, 


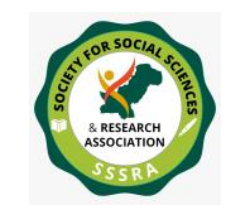

The Core Issue of Stability in Afghanistan...

the United States and Afghanistan Signed a tactical corporation agreement committing both nations to a long-term association. The U.S. Embassy in Kabul began overhaul in late 2001 and was prolonged numerous years later.

Start with a delineation of the history of the two conflicts within the situation of U.S. policies toward Afghanistan, Iraq, and Pakistan-because American policy in the way of aggression and Afghanistan cannot be inferred without some deliberation of Pakistan. The United States military has been affianced in Afghanistan since a moment after the 9/11 attacks in 2001. In 2003, NATO assumed control of the United Nations-mandated International Security Assistance Force Mission (ISAF).

The United States is a fraction of an alliance of more than 100 countries and organizations that grant both protection and inhabitant support to Afghanistan. The United States and further 30 additional nations offer monetary hold up to the ANDSF. The United States remains dedicated to the concord government of Afghanistan that emerged from this course, marking the first autonomous relocate of influence in Afghanistan's history. The concord government has been a consistent and competent cohort for the United States, one which welcomes our security presence and utilizes our development support to enact significant reforms intended at providing Afghans with valuable and comprehensive supremacy, envoy of all segments of society.

Afghanistan lies transversely the critical syntaxes section somewhere the most important ranges of Central Asia converge and successfully terminate, to be replaced crossways by the complementary structural expansion of Iran. The United States' readiness for an indefinite period subsidize Afghanistan with some \$23 billion per year is tentative, especially when al-Qaeda's core has been abridged to incoherence.

The Pakistan-Afghanistan border has become the most hazardous cutting edge on earth and the most crucial for the United States national security interests. The threat to long-term U.S. security interests in this area is neither an economic dilemma, nor a religious problem, nor a generic "tribal" problem (Johnson, T. H., \& Mason, M. C., 2008). As self-preservation against Al Qaeda targets in Pakistan based on the attacks of 9/11, however, is far more exigent, since the requirements of 


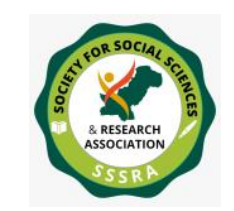

The Core Issue of Stability in Afghanistan...

inevitability and proportionality likely prohibit one-sided uses of force against a third state that was not concerned in those attacks. Pakistan makes itself indispensable to squaring off tasks, offers inadequate expansion aid, opposes Afghanistan's local economic integration, seeks Central Asian energy resources, and pressures the United States to protect Pakistan's wellbeing.

The United States should uphold an active Indian role in Afghanistan to pack the latent security emptiness created by the drawdown of U.S. and North Atlantic Treaty Organization troops. (Murphy, S. D., 2009). The intrinsic right of selfdefense does give a reason for U.S. cross-border operations that act in response to raids by militants from Pakistan into Afghanistan, so long as the U.S. operations linger necessary and proportionate to the peril of those raids, and so long as the Afghan government consents to the existence of U.S. forces. Former US Defence Secretary, Chuck Hagel's proclamation in 2011 that 'India funds nuisance in Pakistan', confessions of Commander Kulbhushan Yadav, and deliberate proclamation made by Ehsanullah Ehsan, Jamaat-ul-Ahrar's former spokesperson, provide ample corroborative facts to prove that India is involved in terrorism, terror-financing and dissident actions in Pakistan. (Times of Islamabad, 2019). The United States should uphold an active Indian role in Afghanistan to pack the latent security emptiness created by the drawdown of U.S. and North Atlantic Treaty Organization troops. (Murphy, S. D., 2009). The long-run probability of success for the USA and its cronies in the region is liable to be diminished by sustained payback terrorist attacks by the Taliban and Al- Qaeda against Afghanis and Pakistanis.

\section{The 9/11 Attack:}

9/11On the evening of September 9th, the NATO meeting started hours after massive attacks and the agenda of the meeting was how to respond to the United States, without the complete data of how the attack happened. The discussion however quickly transformed to one major question: "should article 5 be invoked?" NATO credibility as a defense organization was at the risk and they could not afford to be expressed in a tremble. But it was clear that the invocation of Article 5 was a risk because NATO could not afford to be the part of a dispute which was likely to be personal for the US - the response which included conditions that would be not acceptable or would be hard to get the allies on the table. The 


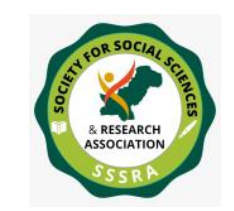

question which bothered them was as, "What if other allies are not willing to take hard decision or The US to decide to alter the multinational response to a nuclear disaster like Japan? What if NATO does not respond to the US call then would it be alone enough to attack while diminishing the value of NATO's credibility and value.

\section{War on Terrorism:}

The shock of $9 / 11$ changed the face of the earth; it was numb and unfathomable the morning of Sept 11, 2001. The USA suffered a lack of life and property. This was the second biggest attack after Pearl Harbor in 1941. This attack works in a domino effect and on 12 September. When the President of the USA at that time, George Washington Bush unleashed its greatest army of the world responding to attacks on twin tower and the pentagon as an "act of war", denominating war on terror groups and those who sheltered the culprits. President Bush was furious and his aim was clear about the future alliance. He tweeted, "Either you are with us or against us". He wanted full support from the world to fight against terrorism. When the USA calls the alliance to declare its full support, NATOs, for the first time, extended and cleared the path for the full-scale corporation to the USA. UNSC resolution 1368, gave the right to individual state or collective state for their right to self-defense. On the call of US President Bush for the war on terror, a coalition against terrorism was created. While American's natural opponents: China and Russia also gave moral support to the cause of terrorism, they considered Al-Qaeda as a greater threat to the internal national security of Moscow and Beijing. European states and the US shared common values and traditions. They were a natural stronghold of each other but after 9/11 NATO's aim did not only open to other parts of the world but also proved to provide a strong military asset and base that would take anything to secure the US interest. Osama Bin Laden and the Al-Qaeda network were the targets of the 9/11 attack. They were accused by the US of being the mastermind of terror attacks in the pentagon and twin tower. Taliban Government in Kabul refused to hand over Osama Bin Laden to the US government.

\section{NATO's Counter-Terrorism Strategy:}

NATO recognizes terrorism as a greater risk for the security of the member states of NATO. In the year of 2002, the Euro-Atlantic members signed and endorsed the 


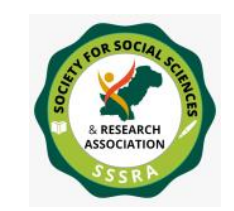

The Core Issue of Stability in Afghanistan...

Partnership Action Plan on Terrorism at the Prague summit. It is a framework of cooperation and partnership role with an instrument for fighting and managing consequences. The strategy of NATO counter-terrorism is built upon the concept of military and offers military actions to minimize the terrorist competence offensively. The model broadly covers two major tasks which are to lead and support.

- NATO in its lead task is countering operations with intelligence structure, control, and command while prepared force to be ready to take action in a crisis.

- Capabilities with proper procedures in detecting attacks with accelerated decision cycles in time-sensitive targets in the counter-terrorist environment.

- More specialized anti-terrorist force which has access to capable and flexible joint fires, ranging from direct conventional fires to precision-guided standoff weapons.

NATO in support is a form of assistance for another international organization that involving its allies with capabilities of undertaking counter-terrorism operations.

- Role to coordinate and backfill the state requirement, deployment of forces on the broader coalition.

- Help to express the political and military operations with planning and commitment for force in like-minded NATO members for force generation.

NATO deployment of troops, aircraft, and ships in several operations against terrorist networks has contributed majorly to counter-terrorism.

\section{Taliban Resurgence:}

According to grey mills who were a special advisor in Kabul, said, "The work of the alliance will be far more difficult because southern Afghanistan is the homeland of Taliban, ousted from power by a US-led coalition in 2001. Most of the southern provinces, particular areas of drug production are the areas which are most closed to Pakistan, said mills". The boundary area between Pakistan and Afghanistan runs between the Pashtun people. So these have traditionally been areas where the insurgency has been and it's fierce. The resistance to control Kabul has been the greatest. And of course, because Pashtuns have resisted and sometimes outright rejected Kabul's role in steering the country from the center. Since the taking over of military operations in Southern Afghanistan, NATO has encountered fierce resistance from Taliban fighters. NATO troops have been increased and casualties have mounted on both sides. 


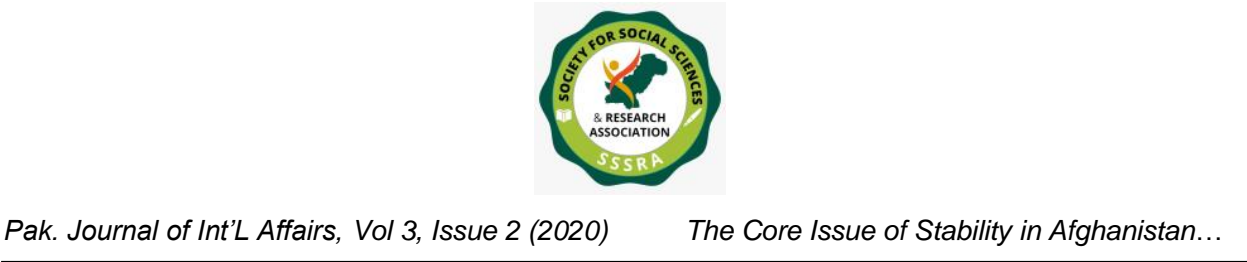

\section{Insurgents Challenge to NATO:}

According to a NATO expert, Charles Kupchan, in the Council on Foreign Relation says, "The insurgents are showing a bit more of an offensive inclination than was originally expected in the sense that we are not just talking now about the off gorilla attack. It can bomb but we are talking about fairly sustained firefights between the substantial formation of Taliban fighters and NATO troops with significant loss of lives on both sides"

\section{NATO Objectives in Afghanistan}

NATO entered Afghanistan through ISAF (international security assistance force). They participated in the reconstruction of Afghan soil. United Nations Security Resolutions 1386, 1413, and 1444 made a mandate for ISAF peace enforcing body. At present 36 nations are in support of ISAF in Afghanistan (E. Hallams 2009.).

The week of attack was a turning point for NATO after the end of the Cold War. Discussions highlighted its agenda that later become the central theme of the year, irrespective of the will to invoke article 5. It's a test for a relationship that could not afford to fall apart. It is confirmed that the grand defense alliance cooperated with the US in their reaction to the war on terrorism, but the US wanted in the direction of use its flight operation and indicated to NATO that it won't ever be the central party of the war. This was a complete embarrassment for the allies. In the history of NATO, It was for the very first time, they invoked an article of 5 and now the US was showing an attitude for a personal response to Afghanistan. The U.S was playing without gloves.

On Aug 11, 2003, NATO initiated its first peacekeeping operation outside European soil, with the support of the US. It gained significant instruments for leverage on moral and political grounds. Political directions were coordinated by NAC which was working closely with non-NATO states in ISAF. Netherland in the allied joint force command, which was managing the operations and training while deploying for sustaining ISAF. PRT - Provincial reconstruction teams lead by ISAF-NATO played a curial role. NATO military-operated in north, west, and south of Afghanistan. Special training was given to local police and the Afghan national army while eliminating weapons. Throughout the constitutional Loyal Jirga 


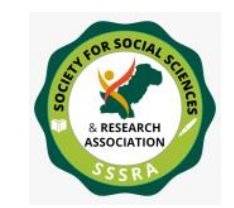

The Core Issue of Stability in Afghanistan...

from Dec 14, 2003, to Jan 4, 2004, they even provided security to them. These tasks made it clear that NATO was playing a supportive role on Afghanistan soil.

The government in Kabul continued to work with UNSC for peace and freedom. NATO mission in Afghan soil is categorized into three parts.

- Dismantle and destroy insurgencies.

- Develop security institutions in Afghanistan to strengthening its infrastructure.

- Cut opium trade.

The USA launched operations, the opening salvo Oct 7, 2001, B-52 drop loads of bombs in Afghan soil. The USA with Canada, Australia, France, and Germany Pledged future support to the anti - Taliban narrative. Northern Alliance along with the anti-Taliban groups and the ethnic with one thousand U.S Special Forces struck on al-Qaeda and Taliban. Later, after 12 days the 1st wave of conventional ground forces arrived.

Combating Insurgencies was always a tough call to make for NATO command in the eastern provinces and the south of Afghanistan. Different troops of Canada and the UK were stationed in the provinces of Helmand and Kandahar; the heartland of Afghanistan. Whereas the lack of coordination helped the insurgency to grow.

Ethnic Uzbek military leader Abdul Rashid Dostum a loyal to the Taliban lost his life at one of the important cities of Afghanistan Mazaar-e- Shareef on 9th November in the year 2001 to the forces. Within a week Taliban's power crumbled. UNSC established a "central role" in the context of transitional administration for the United Nation. The severe confrontation faced by NATO from Attackers in the year of 2007-2008, and anti-government elements were at the peak. The government and the global community demonstrated a willingness to hold consultation with them for bringing back peace. The US Forces Commander in Afghanistan, at that time, was General David Mc Kiernan, who urgently called for at least 10,000 more soldiers as the position of United States and NATO were in defensive. He insisted to talk, and diplomacy was needed to end the bloody war.

Afghan military was incapable and untrained to combat. Security always needs to produce a vacuum of power. According to the Bonn agreement, the international community was bound to create a national army and police as part of their nation- 


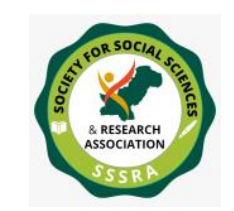

The Core Issue of Stability in Afghanistan...

building process in Afghanistan. NATO provides Afghan forces some weapons and training. The US and EU lead the operation and targeted 70,000 armies and 82,000 police personnel for training. By end of March 2002, ANA - Afghan National Army reached 1725 men. France and USA instructors were deployed for this task. In 2003 due to hard training and discipline out of 8000 men only 1400 complete the academy. By Aug 2005, ANA had central recruiting centers operational in all 34 provinces of Afghanistan. The ultimate objective was to provide only air support to ground troops. By the end of October 2006, Afghan security forces launched their first operation against anti-state elements. They were equipped with international artillery and NATO air support. Also, these trained forces took part in joint military operations with international forces. By the end of March 2007, the Afghan security personals were rose to 41,000 .

The Taliban in the mountains of Tora Bora cave in the southeast of Kabul, Afghanistan militias fought battled for 2 weeks with al-Qaeda. Meanwhile Osama bin Laden left for Pakistan on 16 Dec 2001, despite the intelligence pointing towards bin laden, he escaped to the US did not involve himself in the engagement.

The fall of Kabul opened the door for reconstruction, and the UN got engaged with major Afghan factions like the northern alliance and a group led by the former king. Conference of Bonn, Dec 2001 fractions signed the agreement. Iran's support for northern alliance fraction. Hamid Karzai was selected as interim administration head and created by international peacekeeping forces. Dec 20, 2001, ISAF international security Assistance force-was created.

Taliban surrendered Kandahar and the strongest hold of resistance of Mullah Omar disappeared from Afghanistan and fled to Pakistan under the tribal law administration. Al-Qaeda leaders continued to hide in the mountains but this time without the support of the Taliban - December 9, 2001.

The poppy crop was an important economic indicator and major shareholder in the country's GDP - around 40 percent. Cultivation at that time was massive and concentrated in the southern part of the country. 92 percent of global heroin and opium was produced on Afghan soil. Drug smugglers were in direct contact with President Karzai's family members. But during the Taliban's rule poppy cultivation decreased and during the war, drug smugglers were the main source of funding for 


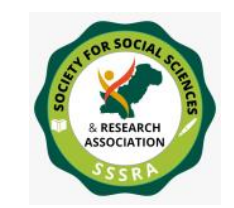

The Core Issue of Stability in Afghanistan...

them. Due to major political and tactical interests, the Kabul government's commitment to eradicate the cultivation of poppy crops did not turn into reality and narcotics even get stronger.

According to the Afghanistan Opium Survey 2007, prepared by the UN Office on Drugs and Crime (UNODC), the production of opium increased 17 percent. Also indicating the largest producer of narcotics in the world, the UN also highlighted the rich financing source for insurgency within Afghanistan and all other criminal illicit activities.

\section{Assessing NATO's Counter-Terrorism Strategies}

NATO emerged as a security counter for the USSR during the cold war, the Soviet Union ended at the end of the cold war, but the established NATO remained and continued to exist. To upgrade the establishment for the future soviet blocked the states and entered its membership. These readjustments like institutionalizing and initiating peace programs with several countries, including Russia were desperate attempts to maintain the influential role in the post-cold war period. Like other systemic changes in the post- 9/11 world, NATO worked as the second line of defense on Afghanistan. In the start, the French supported the USA but after certain concerns that were raised by Germany, Netherlands, and Norway they opposed the NATO operational role in Afghanistan. Bush administration was completely aware of concerns of the European state and their approach towards the war on terror. European states understood the personal issue of America for the campaign against global terrorism that they can be altered. The following are the main points:

- Peace can only be achieved through settlement.

- A need for greater involvement of diplomacy and law enforcement intelligence

- The military operation should be targeted and should be limited

- Clash of civilization must be avoided at any cost.

- United Nations involvement in the formation of the broad international coalition

- States should focus on the root cause of terrorism, and reshape their engagement rules for regional problems. 


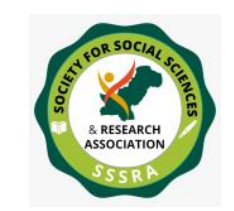

Pak. Journal of Int'L Affairs, Vol 3, Issue 2 (2020)

The Core Issue of Stability in Afghanistan...

It was a clear indication that Americans and Europeans got a different approach to counter-terrorism. The United States agreed to a deal that NATO allies agreed to as well. To take certain steps to supplement the USA in its campaign.

- Greater Intelligence cooperation.

- Made a coalition for state assistance in their approach.

- Increase in the security for US facilities in war zones.

- Aircraft and flights rights for the USA for countering terrorism operations

- Deployment of NATO in the Mediterranean.

As an image of peacekeeper and nation builder, NATO actively supported developing nations in their natural and man-made disasters like the post-earthquake relief mission in Pakistan. The strategic partnership with Pakistan required a high level of engagement with intelligence sharing and this initiated a partnership that converted into the fight against terrorism. The total command of NATO troops was gone up to 30,000 with the contribution of 37 nations but the lead role for NATO in Afghanistan was not acceptable for its allies. The west was divided over NATO as a platform for peacekeeper or use of force. It will continue because the understanding of counterterrorism for the USA and EU got reservations on capability.

\section{NATO Settlements}

NATO got the support to eradicate the $\$ 4$ billion market, so they could attack the processing and smuggling units in target operations. US expressed dissatisfaction with the alliance of NATO and vetoed precise operations. In the year 2007, the war turned into dangerous and striking. Terror attacks increased and Taliban militant changed. Soon the west realized the ground scenario of Afghanistan and accepted that the final solution to this war is a negotiated settlement. Secretary-General Jaap de Hoop Schaffer in April 2007 disclosed that the condition could not be restricted by military force, eventually, dialogue settlement is required

By the end of March 2008, a summit of NATO was held in Bucharest, Romania. The Afghan war was the main agenda. ISAF was under NATOs command for 5 years. The US deployed 17000 soldiers within International Security Assistance Force and 14,000 dealings independently. President Bush sent the largest 


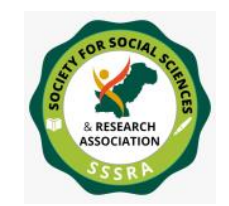

Pak. Journal of Int'L Affairs, Vol 3, Issue 2 (2020)

The Core Issue of Stability in Afghanistan...

shareholder, almost 4 times compared to any other coalition partner. He even requested more from NATO allies against the Taliban but they were not prepared to share troops. In Europe, public sentiments were with settlement through dialogue.

September 11, 2008, after 7 years of world trade Center attacks, Afghan soil became the battleground for the US in the name of the "war on terror". Although initially west won by overthrowing the government of the Taliban and the network of Al-Qaeda in the afghan country. Taliban very effectively re-united to continue the resistance from the tribal areas of Pakistan. They continued to be determined to stay enemies of the States and NATO. Intelligence agencies conducted an operation against the hid outs but Al-Qaeda was still capable of launching terrorist attacks with more intensification. The year 2008 was the deadliest for the US and NATO alliance. 112 soldiers were American and 120 soldiers were from the UK. NATO commanders engaged with insurgents in the south and a major share of army personals while the rest only deployed in the peaceful parts of the country.

In January 2009, the 2 major conferences of NATO were held in the United Kingdom and Europe. Britain was the second largest contributor to troops and finance to NATO in Afghanistan. In both conferences, the NATO head defended itself for not being able to layout the attempts. Defense Secretary John Hutton criticized NATO members for "freeloading on back of US military security". American new President Barack Obama took office on Jan 20, 2009, while Afghan soil had 50,000 soldiers in collation, concerning the top-notch command of the military, 14,000 to 30,000 were more required. The members of the military alliance were a bit less willing to contribute. Barack Obama wanted to forge peace in the war-torn country Afghanistan and ended the Iraq war. He increased more deployment process of US forces up to 34,000. Indicators were clear that the EU, containing NATO on Afghan soil was pure to subservient of US design. Europe and its leaders only view settlement to end this war on terror and developing a tendency to denounce American military adventurism.

President Hamid Karzai reelected his presidential election, but the results were unsettling for the ongoing fraud charges. He allied with the former defense minister who damaged his reputation and credibility due to which the incumbent returned to new elections. British soldiers were dying in the name of US interest in Afghanistan, and this reality became popular among the masses and could not be 


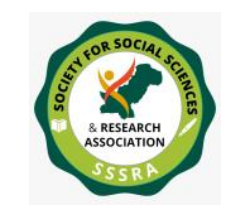

The Core Issue of Stability in Afghanistan...

ignored by the west. By the end of 2009 American combat troops rose more than 97,000 while the more significant factor of Barrack Obama's manifesto was the "Exit Strategy" which is due to mid the year 2011.

NATO members were the biggest contributor of troops after the USA. They were also confused with the Obama exit policy. At that moment 42,000 NATO troops were deployed, but it was on the decline due to uncertain out of area operations. It seemed as if NATO was struggling and working for a cause to survive in the long run of war against terrorism. Olden times will remember that Afghanistan is the graveyard of the world's imperial powers from Spartans to Soviets, and NATO is on the same road.

\section{NATO's Performance}

Its evolution after 9/11 took two different ways. One was clearing the range of demanding mission which was most difficult to achieve, proving to be an important tool for the strength of the transatlantic network. Some say it failed to produce anything, just like operation in Libya, they were useless without the help of the US and Britain. A clear lack of progress indicates the political unwillingness of dragons and biased operation.

\section{The Failure of Global Alliance}

NATO has been fighting the Afghan Taliban since after al-Qaeda bombed the World Trade Center but a look at its operations in Afghanistan could tell you that it hasn't been very successful at limiting the attacks in the land-locked country.

NATO, a military alliance of 30 European and North American countries, failure to beat the Afghan insurgent group puts a big question mark on the very existence of an alliance of global militaries. Michael Williams, an expert on Afghan and NATO affairs at London's Royal United Services Institute, believes that the Taliban knew that the European governments will not be able to fund the war in Afghanistan for very long, so they kept fighting and sometimes they blend back into the Afghan population. "The Taliban has nothing to lose. Time is on their side. They can 


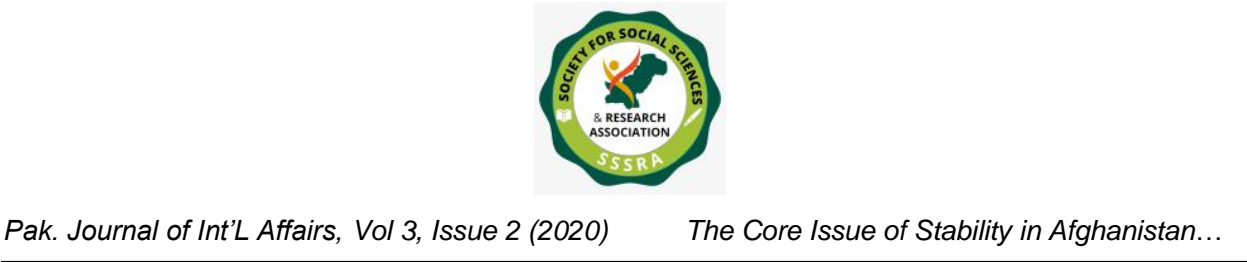

engage intensively for as long as they want. Or they can simply blend back into the population," said Williams.

The expert says the European government panicked after NATO suffered casualties in Afghanistan and the calls of re-enforcements from their top officials remained unanswered. He added that Poland was the only country that agreed to provide its soldiers to NATO but not without a condition. The NATO officials were told the Polish soldiers will not be patrolling in the dangerous southern provinces of Afghanistan.

\section{What Were Their Options?}

Though International Security Assistance Force (ISAF) ended its combat operations in Afghanistan at the end of 2014, some 1,200 NATO soldiers are still there with a role to enhance to defense capabilities of Afghan security institutions to fight terrorism. The NATO 1,200 soldiers won't be enough to fight a force like the Afghan Taliban and other terrorist groups in the region. The global powers, especially after an American exit from Afghanistan, would need a partner in the region to keep the terrorist groups in check.

There is indeed a lesson for NATO to learn from its Afghan operations. It must find a way to rebuild its image in the eyes of the global powers, and for that, it would need to re-structure its role and goals in the international conflicts. You can't enter a war that can last for decades because it makes the member nation tired and make them question the very existence of an alliance.

\section{Unfortunate Afghan Peace Process}

Afghanistan is destined to suffer more violence, regardless of the numerous steps taken for the restoration of peace in this war-torn country. Many factors including mistrust between the negotiating party's forces of status quo in Afghanistan, questionable role of some unseen forces vested interest of the regional players, and most important, non-accommodative behavior of the Taliban and the American have led the afghan peace process into another deadlock. 


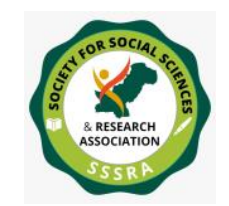

The Core Issue of Stability in Afghanistan...

Zalmay Khalilzad, the US special representative for Afghan reconciliation was about to announce a deal with the Afghan Taliban when the unpredictable President Donald Trump canceled his secret meeting with a delegation of senior leaders of the Taliban group and Afghanistan's President Ashraf Ghani at "Camp David" merely over the killing of an American soldier in an attack claimed by the Taliban. If the level of confidence and trust is such low, it can be predicted easily that even after signing the agreement, its life span would be very short. Rendering is meaningless in the quest for getting the desired results. Although clashes between Taliban fighters and Americans in Afghanistan occur almost daily casualties are part of the fighting yet scuttling the whole process over the killing of a single American soldier brought many factors to the fore. Political advisors of president trump might have advised him to adopt a strategy of cashing the death of the soldier as a key factor for his upcoming elections as a slogan of holding American blood superior over the restoration of peace in Afghanistan.

On the other hand, the Taliban have warned Mr. Trump of seeing many American soldiers be killed in the upcoming days until the signing of the deal with them. Taliban believed that it is their offensive policy on the battlefield that has compelled the Americans to come to the negotiating table. The Taliban had nine meetings with top American interlocutor, Zalmay Khalilzad, for the said deal but they did not stop attacks in Afghanistan for even a single day. They have opted for a "carrot and stick" policy which has worked till this time. Moreover, the Taliban had decided to improve their relationships with other states. They sent a delegation to Moscow where it held a meeting with the Russian representative for Afghanistan Zamir kabulov - which, in a sense, was developing pressure on the Americans to restore the peace process. In their approach, the Taliban were clear that the deal was now a dire need of the American and leaving Afghanistan with a face-saving deal and dignified end of the game for president trump. Moreover, amidst the heated campaign for presidential elections in Afghanistan, insurgency and insecurity have kept the Afghan people on their toes. Taliban have increased their control over many areas and the Afghan security forces are practically unable to counter their attacks. Ashraf Ghani government as well opposition parties are worried over the perilous conditions and are looking up for all-out cooperation by Americans.

Earlier, Ghani had remarked that the Afghanistan security apparatus will collapse within six months if the Americans stopped their support for Afghanistan. Taliban's battlefield successes have also emboldened them and strengthened a perception 


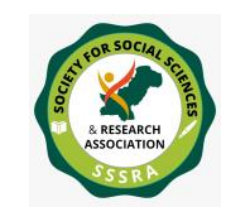

The Core Issue of Stability in Afghanistan...

among the international community as well as Americans that without the Taliban's support, controlling and running the situation of Afghanistan is a dream that will remain unfulfilled. The cancellation of peace talks and calling off the meeting with the Taliban by president trump over the killing of one soldier has brought to naught the ten - the month-long struggle of his own appointed representative, Zalmay Khalilzad. No doubt, Khalilzad has done a lot for bringing the Taliban to this level, which indicates his devotion and commitment to the restoration of peace in his native country and helping Americans in ending the game with an outcome. Khalilzad made several trips to the key states and stakeholders in Afghanistan and held marathon sessions with the Taliban interlocutors in Doha and at other places during this period. Despite the said sacrifices, he has been subpoenaed by the congressional committee asking him to present the reasons behind the failure of the peace process.

The congress and officials in the Trump administration must urge their president to be passionate and adopt an accommodative attitude until the finalization and signing of the peace agreement. Seeking success through diplomatic channels for solving this saga requires the sacrifice of many ideals and achievements from the American side. Donald Trump was seemingly unaware of diplomatic culture and in the said issue, has turned towards has an explicit attitude which proved disastrous for his country's interest in Afghanistan. Furthermore, regional players and key stakeholders in Afghanistan shall also use all channels to convince the Trump administration on utilizing this rare opportunity of ending the game with a peace deal. Pakistan, China, Russia, Turkey, Saudi Arabia, Qatar, and other states should use their diplomatic channels in this regard. It is high time the American and Taliban's bridge the gap of mistrust and moved ahead by sunning the noncooperative behaviors.

Once the process gets stagnated its restoration will need fresh energies and capital from both sides. Istanbul process, more peace talks, quadrilateral coordination group, Kabul process, Moscow process, and many other unofficial endeavors are glaring examples if Americans want to learn some lessons. Perhaps the most important thing is that both parties especially the US should gauge the investment and achievement in the ongoing conflicts. It is apparent from the history of the past two decades that the US has lost much more than gaining some tangible, longlasting results on Afghan soil. Fighting for another two decades will also need negotiations to restore peace. 


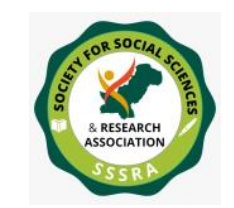

The Core Issue of Stability in Afghanistan...

Before Turing up the American public opinion against the afghan war-like in the case of the Vietnam war- the trump administration should restart negotiations with the Taliban administration for the sake of saving American interest in the region and promoting the culture of solving the issue through negotiations and dialogue.

For America, an Afghan exit wouldn't be an easy task. It can't allow any militant group to make a comeback in Afghanistan but it can't stay in the land-lock country to stop it from happening. America also cannot make its Afghanistan strategic failure make disappear. It would need to understand that it can't blame Pakistan for all its failures because Pakistan didn't invade Afghanistan, the US did.

If the Biden administration continues to follow Trump's deal with the Taliban, it will have to sit with all the regional powers, including Pakistan, Russia, India, and China, to come up with a plan to work out a negotiated settlement in Afghanistan. The US has lost over 4,000 US soldiers and almost 15,000 wounded veterans in the Afghan war and thousands of others were injured in Taliban attacks.

\section{Analysis:}

According to the just war theory, there are three significant parts based on which this scenario will be analyzed.

1) Just ad bellum.

2) Just in bello.

3) Just post bellum.

Under the just war tradition, certain conditions are valid for war to be morally defensible. "The justness of war and the justness of the way that war is fought. These two points - jus ad bellum and jus in Bello, respectively-define the debate over whether a war is moral." (Bass n.d.). When NATO entered Afghanistan, it was unclear with its goals and objectives because they were highly inexperienced in fighting a war outside the Euro-Atlantic region. This is why the war in Afghanistan cost them a lot. Though they were aware of the geographical importance of Afghanistan the allies of NATO disagreed on most of the points and also, America allotted the hardest areas to merely European NATO allies. Though Poland agreed to send thousands of soldiers to Afghanistan initially they were not agreed to petrol 
on southern provinces. It is substantially enough evidence that the JUST ad Bellum rightly proved here. NATO failed to come up with a proper strategy for the Afghanistan mission.

Secondly, thousands of innocent civilians lost their lives in the war. Estimated Yearly Civilian Fatalities as Result of Fighting between Pro-Government Forces and Armed Opposition from 2003 to 2006 ranged from 8,000 yearly to 30,00. The casualties' hit the extreme in 2011 where the casualties yearly would be 35,000 .

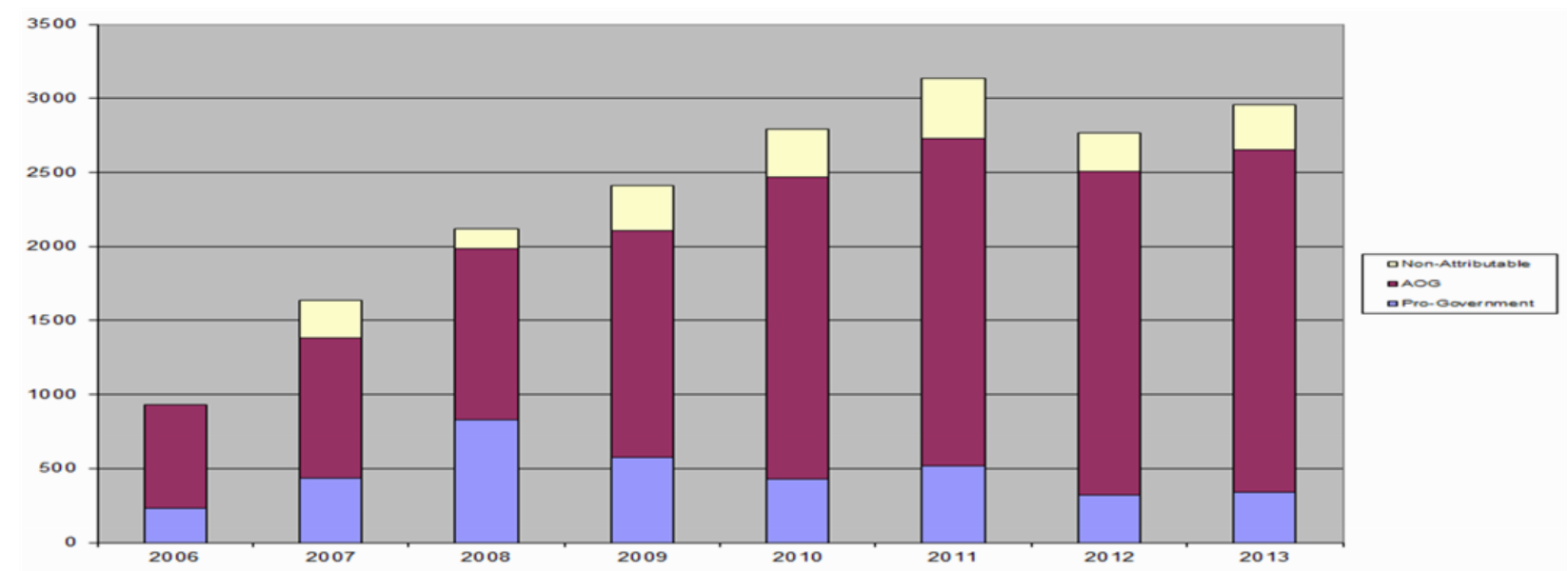

Estimated Percentage of Afghan Civilian Fatalities by Group Which Caused, 20062013. 


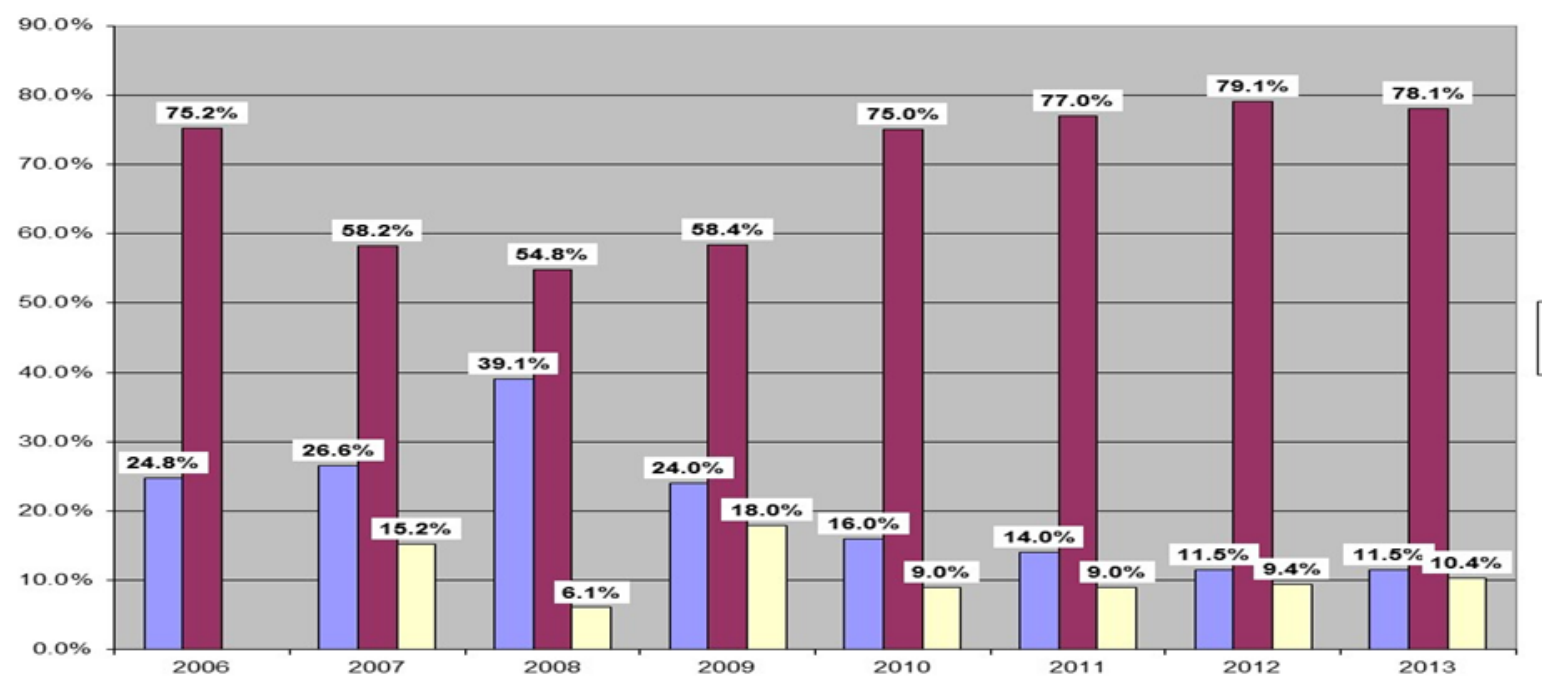

The war once started should proceed properly without any damage to the civilians. Any war which leaves the land devastated is, therefore, a total failure. Which NATO has proven.

Lastly, Orend presents a useful summary of the principles of jus post bellum, saying, "the principle of discrimination should be employed to avoid punishing innocents or non-combatants; the rights or traditions of the defeated deserve respect; the claims of victory should be proportional to the war's character; compensatory claims should be tempered by the principles of discrimination and proportionality; and, controversially, the need to rehabilitate or re-educate an aggressor should also be considered".

NATO came with progressive aims and objectives for Afghanistan which they did not come up with. But according to just post-bellum, especially the political, social, and economic scope of the land is given specific progress and the war-induced crisis are promised to be fixed which NATO did not come up with. Example: Intragovernmental crisis which had led to the conflict between Abdullah Abdullah and Ashraf Ghani for the presidency.

Women's empowerment is abating day by day in Afghan land. A report published by the Brookings Institute says, "Instead of economic, social, and political 


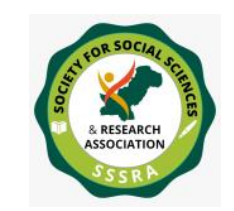

The Core Issue of Stability in Afghanistan...

empowerment, Afghan women in rural areas - where an estimated 76 percent of the country's women live-experience the devastation of bloody and intensifying fighting between the Taliban and government forces and local militias".

Moreover, the paper published says, People in Afghanistan too paid a heavy price of unending war and its consequences. According to a UN report, about 80 percent of Afghan women were victims of domestic violence and some 50 percent are still in jails for committing "moral crimes".

The Afghan Taliban certainly played a big role in the snatching of women's rights but they are not the only ones to blame. Other segments are growing conservative too and they would continue to follow in the footsteps of the Taliban. The US and its partners will have to ensure that the right of Afghan remains protected even after the exit of non-Afghan soldiers and it's impossible without an effective regional alliance.

NATO badly failed in re-settling women's status which is one of the many reasons why wars have failed on the land of Afghans. Education or literacy rate future also has no long-term planning. There has been no concept of restoration of democracy and the Afghan peace process can lead the way ahead now.

\section{Conclusion}

The transformation and evolution of NATO got its special place in history and international relations later by the end of the war between the soviet blocs and western powers. Its existence beyond the cold war raised a question for its role in international relations and purpose for a peacekeeper. How can one explain the basic question of its persistence today? Over history, the NATO alliance growing while in the Afghanistan war generated considerable political reflection of NATO.

The United States of America still holds the leading role in NATO. The reason they continued to lead is a strong relationship with its European allies. The reality is the defense alliance of west that regularly transform itself on the issues of their interest, NATO searched for new operation and goals for its sustainable approach. United Nations and EU witnessed its peacekeeping missions in 1999 in Kosovo, and then 


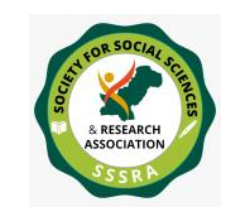

The Core Issue of Stability in Afghanistan...

in 2001 United States of America used NATO as in supportive role due to difference in their understanding of counterterrorism in the Afghanistan war in 2001. After the end of the Taliban regime, the future of Afghanistan was set to be decided by the Security Council of the United Nation (UNSC).

After a request by the Kabul government, ISAF was deployed and authorized on afghan soil in 2001. ISAF-NATO's mission is to rebuild the police and military forces of Afghanistan and led by the European Countries like Germany and Netherlands. When the ISAF-NATO hand over to America, at the same time, another battle opened in the year 2003 with Iraq. The alliance's first task in the gulf belt was Afghanistan which was beyond Europe, and later in the year, 2006 ISAF took full task for the Afghanistan battle not only for peace and stability but for rehabilitations and reconstructions as well.

The time from 2007 - 2008 after 2001 was the deadliest in Afghanistan; the death toll was the highest. NATO unable to counter the insurgency and eradicating opium production, at this point the EU has serious concerns about the line of negotiations that must be held with the Taliban for the end of this war. Because NATO is engaged in the blood bath of its troops, this puts public pressure on the NATO countries for the deeper involvement of EU soldiers into the war-torn country and it's not their war. People started the question and the respective countries started bringing back their soldiers, the people now understand that NATO is used to full fill the American desire and aims to get access to the oil reserves in central Asia. USA bases were already present in Uzbekistan, Kyrgyzstan, and Tajikistan and after 2001 they had in Afghanistan while expanding in 2003 in Iraq. They want to achieve multiple goals, keeping out Russia while encircling Iran. NATO in April 2009 celebrated its 60th birthday and the USA wants more contribution from its allies but no one except Britain willing to send troops on the USA's desire to Afghanistan.

The rigged election for Afghan president at that time Hamid Karzai and the issue of smuggling drugs moreover, the close ties with the tribe's lords also increased the understanding of corruptness of west, they are inefficient and weak, people realized it's a personal aim of Superpower for successfully making them terrorist and change the narrative of masses about it, the paradigm shift of NATO and its sustainable existence required these wars. 
Even after the Karzai Government, the new Afghan president Ashraf Ghani facing a similar issue. No doubt the peace and stability of war-torn land are lying in the smooth relationship between the Afghan government and Taliban, and this is the reason why the historical peace deal between the Taliban groups, Afghanistan, and the USA settled in Doha, Qatar. The Doha deal was aspire to reach the long-awaited peace agreement for Afghanistan but the negotiation somehow still slickly and not as it was expected. The Taliban groups often blame the US and Ghani governments for not abiding by the core agenda of the Qatar deal, i.e. the handing over of Captured people of the Taliban. The US special envoy Zalmay Khalilzad is putting his all efforts to bring both the negotiators on the table again to finally reconcile the long-awaited harmony and constancy in Afghanistan. 


\section{References}

Arbuckle, J. V. (2006). Military Forces In 21 st Century Peace Operations: No Job For A Soldier?. Routledge.

Armitage, R. L., Berger, S. R., \& Markey, D. S. (2010). US strategy for Pakistan and Afghanistan: Independent task force report (No. 65). Council on Foreign Relations.

Auden, J. B. (1974). Afghanistan-West Pakistan. Geological Society, London, Special Publications, 4(1), 235-253.

Begum, I. (1996). The War on Terrorism and NATO's Role in Afghanistan. Organization, 50(3).

Berdal, M., \& Ucko, D. (2009). NATO at 60. Survival, 51(2), 55-76.

Blank, S. (2010). Beyond The Reset Policy: Current Dilemmas of US-Russia relations. Comparative Strategy, 29(4), 333-367.

Boyce, J. K., \& O'Donnell, M. (Eds.). (2007). Peace and the public purse: economic policies for postwar statebuilding. Boulder, CO: Lynne Rienner Publishers.

Brown, F., Allen, John R. and Vanda. (September 2020). The Fate of women in Afghanistan ." Brookings. https://www.brookings.edu/essay/the-fate-ofwomens-rights-in-afghanistan/

Brown, S., \& Scales, R. H. (Eds.). (2012). US policy in Afghanistan and Iraq: lessons and legacies. (Vol. 1). Lynne Rienner Publishers.

Daalder, I., \& Goldgeier, J. (2006). Global NATO :Foreign Affairs, 105-113.

DeFronzo, J. (2018). Revolutions and revolutionary movements. Routledge.

Deshmukh, S. (2018, September 13). The India-Afghanistan-US Triangle Under Trump. South Asian Voice: Regional Affairs. 
https://southasianvoices.org/the-india-afghanistan-us-triangle-undertrump/.

Eurasia Daily Monitor, (2019). Times of Islamabad, Weighing the Impact of Russian LNG in Pakistan. Friday.

Felbab-Brown, V. (2017). President Trump's Afghanistan Policy: Hopes and Pitfalls. Brookings Institution.

Goldgeier, J. M. (2010). The Future of NATO. Council on Foreign Relations. https://www.cfr.org/report/future-nato.

Hallams, E. (2009). The Transatlantic Alliance Renewed: The United States and NATO Since 9/11. Journal of Transatlantic Studies, 7(1), 38-60.

Hallams, E. (2009). The United States and NATO since 9/11: The Transatlantic Alliance Renewed. Routledge.

Hanauer, L., \& Chalk, P. (2012). India's and Pakistan's Strategies in Afghanistan. RAND Corporation.

Harris, G. (Ed.). (2002). Recovery from armed conflict in developing countries: An economic and political analysis. Routledge. 225-257.

Jaeger, D. A., \& Siddique, Z. (2018). Are drone strikes effective in Afghanistan and Pakistan? On the dynamics of violence between the United States and the Taliban. CESifo Economic Studies, 64(4), 667-697.

Johnson, T. H., \& Mason, M. C. (2008). No sign until the burst of fire: Understanding the Pakistan-Afghanistan frontier. International Security, 32(4), 41-77.

Kaim, M. (2008). Germany, Afghanistan, and the Future of NATO. International Journal, 63(3), 607-623.

Khan, R. M. (2015). Foreign Policy of Pakistan in the Changing Regional and Global Settings. Journal of Contemporary Studies, 4(1), 14-30. 
Murphy, S. D. (2009). The International legality of US military cross-border operations from Afghanistan into Pakistan. International Law Studies (US Naval War College), 84.

Nevers, R. D. (2007). NATO's international security role in the terrorist era. International Security, 31(4), 34-66.

O’Hanlon, Ian S. Livingston and Michael. (2015). Afghanistan Index . Washington DC: Brookings .

Ringsmose, J., \& Børgesen, B. K. (2011). Shaping public attitudes towards the deployment of military power: NATO, Afghanistan and the use of strategic narratives. European Security, 20(4), 505-528.

Rühle, M. (2013). Reflections on 9/11: A view from NATO. In NATO beyond 9/11, Palgrave Macmillan, London, pp. 54-66.

Rynning, S. (2012). NATO in Afghanistan: the Liberal Disconnect. Stanford University Press.

Suhrke, A. (2008). A contradictory mission? NATO from stabilization to combat in Afghanistan. International Peacekeeping, 15(2), 214-236.

Tellis, A. J., \& Eggers, J. (2017). US Policy in Afghanistan: Changing Strategies, Preserving Gains. Carnegie Endowment for International Peace.

Thomas, C. (2018). Afghanistan: Background and US Policy. Congressional Research Service, 10.

Webber, M. (2009). NATO: The United States, transformation and the war in Afghanistan. The British Journal of Politics and International Relations, 11(1), 46-63.

Weinbaum, M. G. (2006). Afghanistan and its neighbors: An ever dangerous neighborhood. (Vol. 31). United States Institute of Peace.

Williams, B. G. (2011). On the trail of the 'Lions of Islam': Foreign fighters in _Afghanistan and Pakistan, 1980-2010. Orbis, 55(2), 216-239. 